\title{
Factors on the Accrual Accounting Adoption: Empirical Evidence from
}

\section{Indonesia}

Khoirul Aswart

Universitas Pembangunan Nasional Veteran Jakarta, Jl RS Fatmawati No: 1, Jakarta Selatan/Indonesia

\begin{tabular}{ll}
\hline ARTICLE INFO & ABSTRACT \\
\hline Article History & Purpose: \\
& This study aims to examine the relationship between top management support,
\end{tabular}

Received 11 November 2019;

Accepted 2 February 2020

JEL Classifications

I28, M15, M48, M53 implementation costs, and effective project leader and the level of accrual accounting adoption in Indonesia's municipalities.

\section{Design/methodology/approach:}

The hypotheses of the study were tested using the survey data from 220 municipalites in Indonesia. The instrument for content and construct validity and reliability was tested. Then, the hypotheses were tested using Structure Equation Modelling (SEM) by SmartPLS. Finding:

This study found that, top management support and implementation cost have significant relationship with the level of accrual accounting adoption. Meanwhile, effective project leader has no significant relationship with the level of accrual accounting adoption.

Research limitations/implications:

This study contributions to provide input into the adoption of Government Regulation No. 71 of 2010 in order to apply the rule of accrual accounting to the fullest, and to minimize errors in financial reporting with the identification of possible obstacles faced in implementing accrual accounting. This study recommended that, more factors such as human resources, external audit are needed to complement and improve financial reporting with accrual accounting adoption.

Originality/value:

To the best of the researcher's knowledge, no study of Indonesian municipalities has tested the impact of factor such as top management support, implementation cost, and effective project leader on the level of accrual accounting adoption.

\section{Keywords:}

Accrual Accounting

Adoption, Government

Regulation, Factors,

Indonesia

\section{Introduction}

Since the 1980, the phenomenon has been occurred a change in public sector management style which is characterized by the presence of new public management by adopting the management of the private sector in the public sector (Christensen \& Parker, 2010; Christiaens \& Rommel, 2008; Jagalla, Becker, \& Weber, 2011; Lapsley, Mussari, \& Paulsson, 2009). Changes of management style in the public sector as a result of economic stagnation hit some countries such as New Zealand, Australia and the United Kingdom (Lapsley \& Pallot, 2000; Ball \& Craig, 2010). Based on the new public management (NPM), it is believed to improve performance, financial accountability, asset management, planning, programming and budgeting in the public sector.

The importance of NPM reform can be found in its origins and use of accrual accounting. The adoption of accrual accounting in some countries has been based on the affirmative rationale derived from institutional theory (Christensen, 2005). According to institutional theory, the adoption of new waves of change in an organization is made in response to pressures and external changes. DiMaggio and Powell (1983) identified three mechanisms ${ }^{\dagger}$ Corresponding Author: Khoirul Aswar

Email: aswar_law@yahoo.com 
through which institutional isomorphic changes occur: (1) coercive isomorphism stemming from political influence and the problem of legitimacy, (2) mimetic isomorphism as the standard response to uncertainty, and (3) normative isomorphism regarding professionalization. The three mechanisms tend to arise from different circumstances, so that they produce different results (DiMaggio \& Powell, 1983).

Financial management reform in Indonesia had been running more than a decade since the enactment Law No. 17 of 2003 on State Finance and Law No. 1 of 2004 on State Treasury. In implementing this reform, the financial management of state government should be able to execute in an orderly, efficient, economical, effective, transparent and accountable manner, which is abided by laws and regulations, as stated in Article 3 Para (1), Law No. 17 of 2003. According to Law No. 17 of 2003 on State Finance, it is stipulated that the state financial management should be carried out with the application of good accounting system foundation on robust internal control system. The Law also mentioned that the implementation of an accrual accounting system should cover a period of 5 years starting from 2003 until 2008.

Furthermore, the Indonesian government has issued the Indonesian Government Regulation No. 24 of 2005 concerning Government Accounting Standards as the basis for the implementation of the government accounting system with a cash basis towards accrual basis. This regulation is to enhance public sector organization which has not yet implemented accrual basis accounting due to lack of human resources. This regulation provided a transition period, so that the reporting entity may apply the cash to accrual basis based on the SAP, whereby the transition period is not more than 4 years before the budgeting in 2010. This means that transition period is from 2005 until 2009.

In 2010, the government has published regulation No. 71 of 2010 concerning the SAP as the accrual basis to improve the quality of government performance accountability to replace the regulation No. 24 of 2005. The provisions of transition period in regulation No. 71 of 2010 is published, in part to the effective date imposition Statement of Government Accounting Standards or "Pernyataan Standar Akuntansi Pemerintah" (PSAP) which stated that the PSAP accrual basis is effective for the budget implementation of the Fiscal Year 2010. However, those reporting entities, that has not been able to apply the accrual-based PSAP, this can apply the cash towards accrualbased PSAP at least 4 years after the Fiscal Year 2010. Under these conditions, 2015 was a year where the government accounting system must fully adopt the accrual accounting basis.

There is a sceptical view on the implementation of accrual accounting standards which is based on the mandate of the Government Regulation No. 71 of 2010 , which is at least implemented in 2014 by all reporting entities. It is about how the local government responds and prepare to implement the government accounting standard. The implementation of previous government accounting standard No. 24 of 2005 for the period of 2005-2009, there are still many obstacles faced by central and local government. There is only a small number of the financial statements of central government and regions that received an Unqualified Opinion from the State Audit Board or "Badan Pemeriksa Keuangan” (BPK). In the second half of 2010, BPK has audited 499 Local Governments Financial Report or "Laporan Keuangan Pemerintah Daerah" (LKPD) for the year ending in 2009 and provided over 15 unqualified opinion, 330 Qualified Opinion, 48 Adverse Opinion and 106 Disclaimer Opinions (www.ksap.org/berita).

In Indonesia, there are a few empirical studies on the adoption of accrual accounting. For example, Mcleod \& Harun, (2014) described the challenges which Indonesia faced which tried to reform the public sector accounting to understand the background and the nature of public sector accounting reforms. The findings of the observation that the accrual accounting reform was stymied by a lack of management to support accrual accounting. Harun (2008) provided an overview of public sector reform in Indonesia. He focused on the barriers, improvement, and actions taken by Indonesia to move to accrual accounting. Harun and Kamase (2012) described the institutional capacity of provincial governments and the adoption problems in accrual accounting. Harun, VanPaursem and Eggleton (2012) evaluated the institutionalization of the accrual accounting system in Indonesian local governments using case studies to gain insights in relation to the process of institutionalization in the public sector. McLoad and Harun (2014) described and analyzed the challenges faced in trying to reform public sector accounting in Indonesia. Additionally, previous research has been done in the public sector to look at the process of adopting accrual accounting. Simanjuntak (2010) and Bastian (2006) suggested that the adoption of accrual accounting in Indonesia government requires, top management support, implementation cost, and project leader.

In particular, this paper focuses on the influencing factors which will lead to study in exploring the level of accrual accounting adoption with a focus on the Indonesia Municipalities. Furthermore, the objectives for this study is to examine the relationship between factors such as top management support, implementation costs, and effective project leader and the level of accrual accounting adoption in Indonesia's municipalities.

\section{Literature Review}

Accrual-based accounting is a cornerstone of public sector accounting reforms under the umbrella of NPM (Pessina, Nasi, \& Steccolini 2008) whose main goal is to improve efficiency in public sector decision-making process (Mzenzi, 2013). Accrual accounting is often recognized better than cash accounting mainly because it provides quality information relevant to internal and external users. Accrual accounting can improve transparency, the assets and liabilities of the organization. It also facilitates accounting information comparable between years and also improve the efficiency of decision making in the organization (Lapsley, Mussari, \& Paulsson, 2009).

Accounting changes and public sector reforms resulted in the implementation and adoption of accrual based accounting. This needs to be standardization through accrual accounting in these countries has been spearheaded and influenced by pressure groups, including human factors and political orientation (Pessina, Nasi, \& Steccolini 2008) and 
the United Nations (Lapsley, Mussari, \& Paulsson, 2009; Mzenzi, 2013; Pina, 2007). Change and public sector reform with accrual accounting, including regulatory accounting processes changes such as the introduction of the International Public Sector Accounting Standards (IPSASs) and legislation are more innovative (Lapsley et al, 2009; Mzenzi, 2013; Pina, 2007).

Other changes include participatory budgeting where accountability and transparency are core values, the system changes the accounting and budgetary information, the introduction of performance audits, the introduction of management accounting techniques such new $\mathrm{ABC}$ as well as changes in the skills and competencies needed in the public sector, including local government staff to operate the organization (Lapsley, Missouri, \& Paulsson, 2009; Mzenzi, 2013; Pina, 2007). The implementation and adoption of accrual accounting in the public sector changing nature, required human capabilities and competencies necessary to understand and interpret the accounting information for the decision making process.

Rational technical role of accrual accounting has a significant impact on the utilization of the budget process in decision-making compared with the role of the institutional and political role (Koyabashi, Yamamoto \& Fujii, 2011). It means that the accrual accounting is the process of a public sector budget is used for interaction between the actors through professional skills, knowledge and experience along with the political leadership in decision-making (Koyabashi et al, 2011). Implementation and adoption of accrual-based accounting with a focus on results and outcomes of service provision as well as the delegation of authority to departmental management over their budget allocations and formulation, mode of operation, and compliance with a set of fiscal management has enabled significant improvements in term efficient use of resources and positions government finances (Barton, 2009).

Hypothesis development will be based on the factors that allegedly possess an influence on the level of accrual accounting adoption in Indonesia municipalities, which is formulated as follows:

Top management support is the most studied factors in a successful information system adoption (Dong, 2001) and is also the source of the most difficult in the information system adoption. The common interests of management with previous experience, the reform initiative with accounting practices and the active involvement of managers will be a positive influence on the rate of reform adoption (Ridder \& Bruns, 2006). Similarly, research conducted by Cavalluzzo and Ittner (2004) shows that, top management support has a relationship with the adoption of the measurement system. Research by Jackson and Lapley (2003), showed that managers sometimes resist and impede the practice of accounting. This argument leads to the proposal of the following hypotheses:

$\mathrm{H}_{1}$ : There is a relationship between top management support and the level of accrual accounting adoption.

In a broader narrower context, the local budget is a source of funding of all activities organized by a local government for the benefit or society and the development of government (Kelly and Rivenberk, 2010). Research shows that the potential benefits of accrual accounting may be difficult to achieve, the cost of adoption of accrual accounting is also difficult to estimate although generally accepted substantially. However, some organizations have adopted accrual accounting developed specially for this accounting reform a very good example is the UK case, (Hyndman \& Connolly, 2005). Previous studies on public sector reform has made it clear that the high adoption costs of the new accounting system (e.g., system information changes, staff training, consultants' fees, etc.), will be able to prevent or delay the adoption process as a whole and consequently anticipated (Canby, 1995; Lawson, 2005; Udpa 1996; Ouda, 2008). The adoption of the new accounting system may be refused if the cost is too expensive, although it will be enforced. Thus, the following hypothesis is stated:

$\mathrm{H}_{2}$ : There is a relationship between implementation cost and the level of accrual accounting adoption.

The successful adoption of the new system lies in effective project leader, which is appropriate and effective (Nah, Zuckweiler \& Lau, 2003). Numerous studies in the literature new public management and other reforms suggest the importance of effective project leadership in bringing a successful change (Aggestam, 2010; Newman, Raine \& Skelcher, 2001; Stewart \& Kringas, 2003; Van Wart, 2003), despite considerable agreement that the success or failure of the reforms depends on the leadership role. There is a wide diversity of definitions and interpretations of the concept of effective project leadership. Furthermore, Hartley and Allison (2000) in a paper titled "effective project leadership" viewed it as a combination of assigned project leaders in executive positions (secretary or treasurer), which provides visible leadership, communicative, and accountable. As discussed above, the project leader is critical to the successful adoption of accrual accounting. Thus, the following hypothesis is stated:

$\mathrm{H}_{3}$ : There is a relationship between effective project leader and the level of accrual accounting adoption.

\section{Research Methodology}

The data from the questionnaire survey sent to respondents by e-mail, or personally delivered to 273 head accountant section of municipalities. Indonesia would be divided into 7 (seven) island geographical zones namely: Java and Bali, Sumatera, Kalimantan, Sulawesi, Papua, Nusa Tenggara, Maluku. Each geo political zone represents a cluster. First of all, 1 zones (clusters) would be selected from the 7 geographical zones. After selecting the two zones, the next step is to randomly select 119 for Java island, 154 for Sumatera island, making a total 273 municipalities. Finally, a simple random sampling would be used to select 1 respondent from each of the selected municipalities which will finally give the sample size of 273 respondents.

Personal presence and monitoring by the researcher and follow-up by accountant sections heads resulted in the return of two hundred twelve (212) questionnaires, representing a gross response rate of $77 \%$. Follow-up continued 
for the remaining questionnaires of sixty-one (61); however, none of them were returned. Ten (10) questionnaires were checked and found to be incomplete, therefore eliminated. Finally, the net responses used in this study were two hundred and two (202), representing a net response rate of $74 \%$ of the gross responses.

\subsection{Measurement of Variables}

The questionnaire elicited responses on the level of accrual accounting adoption, top management support, implementation cost, and effective project leader. This variable under review was measured using multiple items. Existing well established measures were used with modifications to the current research context.

\subsubsection{The level of accrual accounting adoption}

In the context of this study, the level of accrual accounting adoption has been operationalized as the perceptions of the heads of accountant sections based on the compliance index. This variable is adopted from Aswar \& Saidin, (2018) based in Indonesia context. PP No. 712010 in accordance with the GAS categorize items of accounting accrual to achieve level of accrual accounting adoption. The items category includes information about completeness, valuation, classification, mechanical accuracy, disclosure, formalistic requirements, and adequacy and usefulness. The characteristics specified by PP 71 of 2010 on GAS for the level of accrual accounting adoption consists 43 elements that were used as a construct of the compliance index.

\subsubsection{Top Management Support}

Top management support was measured by the degree of management to encourage and facilitate the adoption of accrual accounting through leadership, working environment and provision of critical resources (Finney \& Corbett, 2007; Nah \& Delgado, 2006). This variable is adapted from the work of Taylor and Wright (2004), Lin (2014) with some modifications. The instrument contains 7 items. The original items and the modified ones are presented in Appendix D. This measurement would be expressed on a 5-point rating scale, ranging from 5-strongly agree to 1strongly disagree.

\subsubsection{Implementation Cost}

Implementation costs is the cost in determining the volume of financial resources necessary for the overall transition process and can help to overcome the financial problems in the future by having a gradual transition to full accrual accounting and budgets (Ouda, 2008). The adoption of accrual accounting requires funding in enforcing accounting regulations of certain legal entities. These costs include training, research, technology, and consulting cost (Deloitte \& touch, 2011). The instrument contains 8 items. This variable is self-developed by researcher from the work of Connolly \& Hyndman (2006). This measurement would be expressed on a 5-point rating scale, ranging from 5-strongly agree to 1-strongly disagree.

\subsubsection{Effective Project Leader}

Effective project leader was measured using an instrument developed by Nah et al. (2009), Sofwan Winarno \& Najib (2014) with some modifications. The instrument contains 5 items. Effective project leader is supporting from upper management plan is developed and managed new accounting and the new accounting policy is written at the right time (Aggestam, 2010). This project should be well documented, have a formal adoption plan, the allocation of responsibility for various tasks assigned and monitor their performance (IFAC, 2011). This variable is adapted from the work of. This measurement would be expressed on a 5-point rating scale, ranging from 5-strongly agree to 1strongly disagree.

\section{$4 \quad$ Results and Discussions}

\subsection{Descriptive Analysis}

Descriptive analysis of the study reveals that, $55.4 \%$ of the total respondents are male, while the remaining $44.6 \%$ of the respondents are female. This is clearly revealed the dominance of male personal head of accounting sections in Indonesian municipalities. By looking at the age of respondents was grouped into four different categories. The group aged 25-45 years was found to be the largest group representing 51.5\% of the total sample population followed by age category 46-55 years representing 40.1\%. These two category groups cover $91.6 \%$ of the total respondents. Regarding the educational level of the respondents. Table 6.7 clearly shows bachelor degrees -university graduates represented the largest group with $57.9 \%$ followed by those who hold a master degree with $39.6 \%$. The last category had a doctorate totalling 2.5\%. These two categories (bachelor and master) totalling $97.5 \%$ represented the majority of the population. This categorization indicates a high level of education level and professionalism.

\subsection{Results}

This part of the study utilizes the Statistical Package for Social Science (SPSS) release 23 for Windows to analyse the data. However, further data exploration reveals that, no identified case of univariate outliers was established. This implies that, the calculated Z-scores of all the variables under review falls within the acceptable threshold (Tabachnick \& Fidell, 2007).

Reliability of the instruments were also computed, thus all the variables in the study reveals acceptable Cronbach alpha reliability co-efficient. Thus, the Cronbach alpha co-efficient of the level of accrual accounting adoption, top management support, implementation cost, and effective project leader are 0.781, 0.932, 0.967 and 0.827 respectively. These have exceeded the recommended minimum (Nunnally and Bernstein, 1994). 
Moreover, normality assumption is the most vital assumption in the bivariate and multivariate statistical analysis (Hair et al., 2010). Therefore, this study utilized histogram method of achieving normal distribution which easily and graphically presents histogram and the normal distribution curve. This is more visibly straightforward than using numeric method (Kolmogorov-Smirnov test).

In order to satisfy the assumption of linearity and homoscedasticity, the scatterplots were plotted to ascertain the direction of the relationship between the variables. The scatterplots indicate that, the scores of the plots cluster uniformly around the regression line, hence, linearity and homoscedasticity are assumed. The regression line that passes through the data points represent the "line of best fit."

\subsection{Test of Hypothesis}

\subsubsection{Top management support and the level of accrual accounting adoption}

Top management support is one of the most studied factors in accrual accounting adoption (Cohen et al, 2007; Cohen et al, 2012). Top management support has a very important role in achieving the goals and objectives of implementation as well as the organization's (Harun, 2008; Simanjuntak, 2010). The results of this study indicate that top management support has a significant effect on the level of accrual accounting adoption $(\mathrm{T}=2.314$, sig=0.22), which means $\mathrm{H}_{1}$ can be accepted. These findings are in line with other accounting implementation studies which explain top management support as the key to the successful implementation of accrual accounting (Ridder \& Bruns, 2006; Cavalluzzo \& Ittner, 2004; Dong, 2001; Jackson \& Lapley, 2003). In the context of the accrual accounting adoption rate in municipalities, the presence of peak management support is very vital because the accrual accounting adoption is large and complex process and requires a lot of resources. With the commitment and support of top management for the necessity of adopting accrual accounting, vital resources will likely be made available to facilitate the adoption process.

\subsubsection{Implementation cost and the the level of accrual accounting adoption}

The implementation cost within the organization shows a significant positive effect on the level of accrual accounting adoption $(\mathrm{T}=2.035$, Sig=0.45). The results of this study therefore accepted $\mathrm{H} 2$. This phenomenon can occur if the implementation cost is not well defined and ineffective, thereby reducing the intention of using accrual accounting adoption. These results are not in line with public sector reform studies (Canby, 1995; Lawson, 2005; Udpa 1996; Ouda, 2008). However, the results found are consistent with Eriotis et al. (2011) which showed a small rate of adoption in cost of accounting systems in hospitals. It is suggested that traditionally hospital had small incentive amount or demand for cost accounting systems as its management control rule. Hospitals primary report written to the external funding authorities (government), hence they only focused on external reporting factors.

\subsubsection{Effective project leader and the level of accrual accounting adoption}

The effective project leader was also discovered to have no significant impact on the level of accrual accounting adoption $(\mathrm{T}=1.315$, Sig=0.092), which means H6 is rejected. This result also contradicts the research of new public management reforms (Aggestam, 2010, Stewart \& Kringas, 2003; Newman et al., 2001; Van Wart, 2003) as well as other enterprise systems ( $\mathrm{Nah}$ et al. 2003; Somers \& Nelson, 2001). The reason is likely because the adoption of accrual accounting considered as a project of the central government while the municipalities is the basis for its implementation. Project management, business alignment - technology and overall work process changes are developed and designed by the central government. Thus, project management undertaken by project managers in the centre has no effect on the level of accrual accounting adoption in the municipalities. Basically, the project management program is important (Harun, 2008; Jiang et al., 1996). However, in the context of adoption of accrual accounting, an effective project leader may have a significant effect on accrual accounting adoption success rate if implemented on central government level.

\section{Conclusions, Limitations and Recommendations}

This purpose of this study was demonstrating the need and relevance the level of accrual accounting adoption in Indonesian's municipalities by using a compliance index. This is important because Indonesia has recently undergone major government financial reform and is seeking to greatly enforce its financial accounting transparency (Rosser, 2009). The level of compliance index in this thesis is measured using a 43-item index derived from the key Indonesian Government Accounting Standards (PP No.71 of 2010) to explore in greater depth the relationship between the level of accrual accounting (as measured by the compliance index) and key predictor variables in the government institutions. This study findings are expected to make significant contribution to improve transparency and accountability of the government by factors on the level of accrual accounting adoption, particularly for the Indonesian municipalities. Top management support, implementation cost, and effective project leader also influence the level of success in the accrual accounting adoption process.

The empirical findings of this thesis are potentially important for regulatory bodies, municipalities, the central government, and users of municipalities financial reports. These findings can be applied to developing and improving public sector governance applications. In particular, these findings may serve as input for public policy making in the implementation of PP. 71 of 2010 in order to ensure its full implementation in all Indonesian government institutions. Therefore, it can be concluded that there is a relationship between top management support, and implementation cost on the level of accrual accounting adoption. Meanwhile, the hypotheses H3 not supported, it can be concluded that 
there is no relationship between effective project leader on the level of accrual accounting adoption in Indonesian municipalities.

This study uses only three independent variables which are factors of internal municipalities and does not consider other institutional factors or other wider social factors which may have a significant effect on the level of accrual accounting adoption. Furthermore, the findings of this study and the limitations inherent in it can lead to some further research opportunities. Further research can examine the relationship between the level of accrual accounting adoption and the broader social and institutional forces that surround it and consider including other important contextual variables that have been omitted from other studies and are likely to influence compliance levels. The most neglected variables are size of organization, geographic location, and social capital. In addition, the importance of organizational variables such as support from external audits and central and local political support should not be underestimated.

\section{References}

Aggestam, C. (2010). A project management perspective on the implementation of accrual based IPSAS: Copenhagen Business School.

Anessi-Pessina, E., Nasi, G., \& Steccolini, I. (2008). Accounting Reforms: Determinants of Local Governments Choices. Financial Accountability \& Management, 24(3), 321-342.

Aswar, K., Saidin, S.Z. (2018). Accrual Accounting Adoption in Java Municipalities: An empirical investigation. International Journal of Business and Economic Sciences Applied Research, 11(3), 24-30.

Ball, A., \& Craig, R. (2010). Using Neo-institutionalism to advance social and environmental accounting. Critical Perspectives on Accounting, 21(4), 283-293.

Bastian, I, (2006), Sistem Perencanaan dan Penganggaran Pemerintahan Daerah di Indonesia, Salemba Empat, Jakarta.

Barton, A. D. (2009). The Use and Abuse of Accounting in the Public Sector Financial Management Reform Program in Australia. Abacus, 45. 221-248.

Canby IV, J. (1995). Applying activity-based costing to healthcare settings. Healthcare Financial Management, 49 (2), $50-55$.

Cavalluzzo, K. S., \& Ittner, C. D. (2004). Implementing performance measurement innovations: Evidence from government. Accounting, Organizations and Society, 29(3-4), 243-267.

Christensen, M. (2005). The "third hand": Private sector consultants in public sector accounting change. European Accounting Review, 14(3), 447-474.

Christensen, M., \& Parker, L. (2010). Using ideas to advance professions : public sector accrual accounting. Financial Accountability E Management, 26(3), 246-267.

Christiaens, J., \& Rommel, J. (2008). Accrual accounting reforms: only for businesslike (parts of) governments. Financial Accountability \& Management, 24(1), 59-75.

Cohen, S., Kaimenakis, N., \& Venieris, G. (2012). Reaping the benefits of two worlds. Journal of Applied Accounting Research, 14(2), $165-179$

DiMaggio, P. J., \& Powell, W. W. (1983). The iron cage revisited: institutional isomorpfflsm and collective rationality in organizational fields. American Sociological Review, 48, 147-160.

Dong, L. (2001). Modelling top management influence on ES implementation. Business Process Management Journal, 7(3), 243-250.

Eriotis, N., Stamatiadis, F., \& Vasiliou, D. (2011). Assessing accrual accounting reform in greek public hospitals: an empirical investigation. International Journal of Economic Sciences and Applied Research, 4 (1), 153-184.

Government Regulation 24 (2005). Government Accounting Standards.

Government of Indonesia, (2004). Undang-Undang: Pembentukan Peraturan Perundang-Undangan. No. 10/2004. Jakarta, Indonesia.

Government Regulation 24 (2005) on Government Accounting Standards "Standar Akuntansi Pemerintahan" (SAP

Harun, H. (2008). Obstacles to Indonesian public sector accounting reforms. Bulletin of Indonesian Economics Studies, 43 (3), $365-375$.

Harun, H., \& Kamase, H. P. (2012). Accounting change and institutional capacity : the case of a provincial government in Indonesia. Australasian Accounting Business Eं Finance Journal, 6(2), 35-50.

Hartley, J. \& Allison, M. (2000). The role of leadership in the modernization and improvement of public services. Public Money and Management, $20(2), 35-40$.

Harun, H., Peursem, K. Van, \& Eggleton, I. (2012). Institutionalization of accrual accounting in the Indonesian public sector. Accounting \& Organizational Change, 8(3), 257-285.

Hyndman, N. \& Connolly, C. (2005). The impact of introducing resource accounting in Northern Ireland. London: ACCA.

International Federation of Accountants - Public sector committee (2002), study 14: transition to the accrual basis of accounting: Guidance for Governments and Government Entities (IFAC, New York).

Jackson, A., \& Lapley, I. (2003). The diffusion of accounting practices in the new "managerial" public sector. The International Journal of Public Sector Management, 16 (5), 359-372.

Jagalla, T., Becker, S. D., \& Weber, J. (2011). A taxonomy of the perceived benefits of accrual accounting and budgeting: Evidence From German States. Financial Accountability \& Management, 27(2), 134-165.

Jiang, J. J., Klein, G., \& Balloun, J. (1996). Ranking of system adoption success factors. Project Management Journal, $27,49-53$.

Kelly, J.M., \&W.C. Rivenbark. (2010). Performance budgeting for state and local government. New York: M.E. Sharpe.

Kobayashi, M, Yamamoto, K, \& Fujii, H (2011). Usefulness of accrual information in non-mandatory environment: the case of Japanese Local Government. 13th Biennial CIGAR Conference Bridging public sector and non-profit sector accounting, Ghent, June 910 .

Lapsley, I., Mussari, R., \& Paulsson, G. (2009). On the adoption of accrual accounting in the public sector: a self-evident and problematic reform. European Accounting Review, 18(4), 719-723.

Lapsley, I., \& Pallot, J. (2000). Accounting, management and organizational change: A comparative study of local government. Management Accounting Research, 11(2), 213-229.

Lawson, R.A. (2005). The use of activity based costing in the healthcare industry: 1994 vs 2004: Research in Healthcare Financial Management, 10, (1). 
Lin, H. F (2014). Contextual factors affecting knowledge management diffusion in SMEs. Industrial Management $\mathcal{E}^{\circ}$ Data Systems, $114(9), 1415-1437$.

Mcleod, R. H., \& Harun, H. (2014). Public Sector Accounting Reform at Local Government Level in Indonesia. Financial Accountability \& Management, 30(4), 238-258.

Ministry of Home Affairs. 2002. Official website of the Ministry of Home Affairs of Indonesia. From: http://www.kemendagri.go.id/produkhukum/ 2002/06/10/keputusan-mendagri-no-29-tahun-2002 (accessed: September 9, 2016).

Mzenzi, S (2013). 'Accounting practices in the Tanzanian Local Government Authorities (LGAs): The grounded theory of manipulating legitimacy'. PhD thesis, University of Southampton.

Nah, F., Zuckweiler, K., \& Lau, J. (2003). ERP implementation: Chief information officers' perceptions of critical success factors. International Journal of Human-Computer Interaction, 16(1), 5-22.

Nah F.H., \& Delgado, S. (2006). Critical success factors for enterprise resource planning adoption and upgrade. Journal of Computer Information Systems, 47, 99-113.

Nah, F. H., Islam, Z., and Tan, M (2009). Empirical asssessment of factors influencing success of enterprise resource planning implementations. Information Science Reference, 278-299.

Newman, J., Raine, J. \& Skelcher, C. (2010). Transforming local government: innovation and modernization. Public Money and Management, 21 (2), 61-68.

Nunnally, J.C., Bernstein, I.H. (1994), Psychometric Theory. $3^{\text {rd }}$ ed. New York: McGraw Hill.

Ouda, H. (2008). Towards a generic model for government sector reform: the New Zealand experience. International Journal of Governmental Financial Management, 8(2), 91-115.

Pina, V (2007). Accrual accounting in the public sector: Why this successful trajectory?. Government and Non-profit Section 2007 Midyear Conference, Norwalk, Connecticut, March 2-3.

Ridder, H., \& Bruns, H. And Spier. F (2006). Managing adoption processes. Public Management Review, 8(1), 87-1 18.

Rosser, A. (2009). The political economy of accounting reform in developing countries. The case of Indonesia. Asia research Centre. Working Paper No. 93. Murdoch University. Perth. Australia.

Simanjuntak, B. H. (2010). Menyongsong era baru akuntansi pemerintahan di Indonesia. In Disampaikan pada Kongres XI Ikatan Akuntan Indonesia. $1-15$.

Sofwan, M., Winarno, W., Najib, W. (2014). Evaluation factors influencing success of SIPKD Implementation: Case study in the Government of Tana Toraja. Seminar Nasional Teknologi Informasi dan Multimedia,37-42.

Somers, T. M., \& Nelson, K. (2001). The impact of critical success factors across the stages of enterprise resource planning adoptions. Proceedings of the 34th Hawaii International Conference on System Sciences, Wailea Maui, Hawaii.

Stewart, J. \& Kringas, P. (2003). Change management - strategy and values in six agencies from the Australian Public Service. Public Administration Review, 63 (6), $675-688$.

Tabachnick, B., \& Fidell, L. (2007). Using multivariate statistics New York: Allyn and Rose.

Taylor, W.A. \& Wright, G.H. (2004). Organizational readiness for successful knowledge sharing: challenges for public sector managers. Information Resources Management Journal, 17(2), 22-37.

Udpa, S. (1996). Activity-based costing for hospitals. Health Care Management Review, 21 (3), 82-96.

Van Wart M. (2003). Public-Sector Leadership Theory: An Assessment. Public Administration Review, 63 (2), $214-228$.

This is an Open Access article distributed under the terms of the Creative Commons Attribution Licence

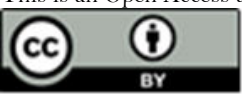

